\title{
Friction and Wear Properties of Copper/Carbon/RB Ceramics Composite under Electrical Current
}

\author{
Kei Shibata ${ }^{1)^{*}}$, Takeshi Yamaguchi ${ }^{1)}$, Yuta Yao ${ }^{1)}$, Nobuyuki Yokoyama ${ }^{2)}$, Junichiro Mishima ${ }^{2)}$ and Kazuo Hokkirigawa ${ }^{1)}$ \\ ${ }^{1)}$ Graduate School of Engineering, Tohoku University \\ 6-6-01 Aramaki Aza-Aoba, Aoba-ku, Sendai, Miyagi 980-8579, JAPAN \\ ${ }^{2)}$ East Japan Railway Company \\ 2-2 Yoyogi 2-chome, Shibuya-ku, Tokyo 151-8578, JAPAN \\ *Corresponding author: shibata@gdl.mech.tohoku.ac.jp
}

( Manuscript received 23 October 2009; accepted 19 November 2009; published 30 November 2009 )

\begin{abstract}
Friction and wear properties of the copper/carbon/RB ceramics $(\mathrm{Cu} / \mathrm{C} / \mathrm{RBC})$ composite were investigated under electrical current with and without arc-discharge. The weight fraction and the mean diameter of RB ceramics powder were $5 \mathrm{wt} \%$ and $4.9 \mu \mathrm{m}$, respectively, in the $\mathrm{Cu} / \mathrm{C} / \mathrm{RBC}$ composite. Friction tests were conducted with the block-on-ring friction apparatus. The $\mathrm{Cu} / \mathrm{C} / \mathrm{RBC}$ and the copper/carbon $(\mathrm{Cu} / \mathrm{C})$ composite, the conventional pantograph slider material of a railway current collector, were used as block specimens. Under electrical current without arc-discharge, the $\mathrm{Cu} / \mathrm{C} / \mathrm{RBC}$ composite showed $98 \%$ reduction in the specific wear rate of the block specimen, $23 \%$ reduction in that of the ring specimen, and $75 \%$ reduction in the friction coefficient over the conventional $\mathrm{Cu} / \mathrm{C}$ composite. Under electrical current with arc-discharge, the $\mathrm{Cu} / \mathrm{C} / \mathrm{RBC}$ composite showed the wear resistance to arc-discharge equivalent to the conventional $\mathrm{Cu} / \mathrm{C}$ composite.
\end{abstract}

Keywords: arc-discharge, electrical current, composite, friction, pantograph slider, RB ceramics, wear

\section{Introduction}

Pantograph sliders of a railway current collector require several characteristics such as low electrical resistivity, high strength, high wear resistance and low aggression to contact wires. Recently, reduction in maintenance costs of a pantograph system has been also desirable. Thus, a pantograph slider material requires higher wear resistance and lower aggression than the conventional pantograph slider material, the copper/carbon $(\mathrm{Cu} / \mathrm{C})$ composite ${ }^{1)}$.

In our previous work, the copper/carbon/RB ceramics $(\mathrm{Cu} / \mathrm{C} / \mathrm{RBC})$ composites were developed ${ }^{2}$. $\mathrm{RB}$ ceramics are hard porous carbon materials made from rice bran as a main constituent ${ }^{3-6)}$. RB means the acronyms of rice bran. On the basis of pin-on-disk friction tests under non-electrical current, the $\mathrm{Cu} / \mathrm{C} / \mathrm{RBC}$ composites showed tribological properties superior to the $\mathrm{Cu} / \mathrm{C}$ composite. Especially, the $\mathrm{Cu} / \mathrm{C} / \mathrm{RBC}$ composite showed the highest wear resistance, low aggression, and a low friction coefficient when the weight fraction and the particle diameter of $\mathrm{RB}$ ceramics powder were $5 \mathrm{wt} \%$ and 4.9 $\mu \mathrm{m}$, respectively ${ }^{2}$.

A pantograph slider's actual working condition implies sliding against a contact wire under electrical current. Hence, the $\mathrm{Cu} / \mathrm{C} / \mathrm{RBC}$ composite required a clarification of friction and wear properties of under electrical current to be applied actual pantograph sliders.

On the basis of the background described above, the friction and wear properties of the $\mathrm{Cu} / \mathrm{C} / \mathrm{RBC}$ composite $\left(\alpha=5 \mathrm{wt} \%, d_{\mathrm{m}}=4.9 \mu \mathrm{m}\right)$ under electrical current with arc-discharge and without arc-discharge were investigated.

\section{Experimental procedure}

\subsection{Sample preparation}

Figure 1 shows a schematic diagram of the preparation process of the $\mathrm{Cu} / \mathrm{C} / \mathrm{RBC}$ composite block specimen. The $\mathrm{Cu} / \mathrm{C} / \mathrm{RBC}$ composite was prepared by forming a compound of copper, carbon, and RB ceramics powders into a block shape. Then, the formed block was sintered in an inert gas. The conventional pantograph slider material, the $\mathrm{Cu} / \mathrm{C}$ composite, was also prepared as a comparison. Each composite was cut into the block shape $(25 \mathrm{~mm} \times 60$ $\mathrm{mm} \times 10 \mathrm{~mm}$ ), and then their test surfaces were finished by grinding. The surface roughness $\mathrm{Ra}$ of the $\mathrm{Cu} / \mathrm{C} / \mathrm{RBC}$ and the $\mathrm{Cu} / \mathrm{C}$ composite were 1.6 and $1.8 \mu \mathrm{m}$, respectively. Table 1 shows composition ratios and mechanical, electrical properties of each composite. The $\mathrm{Cu} / \mathrm{C} / \mathrm{RBC}$ 


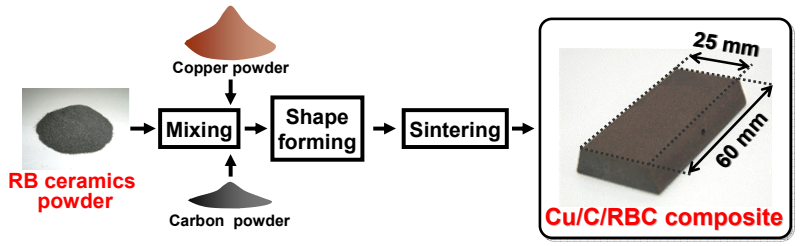

Fig. 1 Schematic diagram of preparation process of $\mathrm{Cu} / \mathrm{C} / \mathrm{RBC}$ composite

composite satisfied the bending strength requirement of 70 $\mathrm{MPa}$ and the electrical resistivity requirement of $3 \mu \Omega \cdot \mathrm{m}$. Figure 2 shows optical microscope images of the buffed surfaces of each composite.

\subsection{Experimental apparatus}

Figure 3 shows the block-on-ring friction apparatus used under electrical current. Block specimens were the $\mathrm{Cu} / \mathrm{C}$ and the $\mathrm{Cu} / \mathrm{C} / \mathrm{RBC}$ composites. A ring specimen as a simulated contact wire was an oxygen-free copper ring of $5 \mathrm{~mm} \times 45 \mathrm{~mm}$ rectangular cross-section with a chamfered edge. The ring specimen set on the periphery of a rotation disk with a diameter of $1000 \mathrm{~mm}$. Normal load was applied with a spring attached on the block specimen. Contact points between the block specimen and the ring specimen reciprocated with sinusoidal amplitude of $50 \mathrm{~mm}$ on the block specimen.

\subsection{Experimental condition}

Table 2 shows the experimental condition. The normal load $W$ was $49 \mathrm{~N}$ (the corresponding apparent contact pressure $P$ was $0.39 \mathrm{MPa}$ ). The sliding velocity $v$ was $27.8 \mathrm{~m} / \mathrm{s}$. The voltage of power supply $E$ was DC $100 \mathrm{~V}$. The direction of electrical current was from a ring specimen to a block specimen. Friction tests were conducted under electrical current with and arc-discharge at the ambient temperature of $12 \pm 2$ degrees $\mathrm{C}$ and the relative humidity of $54 \pm 12 \% \mathrm{RH}$.

Under electrical current without arc-discharge, an electrical current of 100 A was applied. A surface of a ring specimen was treated with 60 grid sandpapers and thereby the surface roughness of the ring specimen $R \max$ was $12 \mu \mathrm{m}$.

Under electrical current with arc-discharge, large surface roughness of a ring specimen promoted occurrence of contact breaks. The test surface of a ring specimen was treated by the following process. The surface of the ring specimen was treated with 60 grid sandpapers. Then, the polished surface was slid on a copper-based sintered metal alloy at the sliding velocity of $6.9 \mathrm{~m} / \mathrm{s}$ under the electrical current of $100 \mathrm{~A}$ for 10 minutes. Consequently, the range of the surface roughness of the ring specimen $R_{\max }$ was from 15 to $60 \mu \mathrm{m}$. After that, the treated ring specimen was slid on the $\mathrm{Cu} / \mathrm{C}$ and the $\mathrm{Cu} / \mathrm{C} / \mathrm{RBC}$ composites under the electrical current range from 100 to 400 A for 10 minutes. This abrasion process of the ring specimen and the friction tests were repeated for three times for each set of friction tests.

Specific wear rates of the block specimens were calculated based on a weight loss measured with the
Table 1 Composition ratios and mechanical, electrical properties of each composite

\begin{tabular}{|c|c|c|c|}
\hline \multicolumn{2}{|c|}{ Composite materials } & $\begin{array}{c}\mathrm{Cu} / \mathrm{C} \\
\text { (conventional) }\end{array}$ & $\mathrm{Cu} / \mathrm{C} / \mathrm{RBC}$ \\
\hline \multicolumn{2}{|c|}{$\begin{array}{c}\text { Mean diameter of } \\
\text { RBC powder } d_{\mathrm{m}}, \mu \mathrm{m}\end{array}$} & & 4.9 \\
\hline \multirow{3}{*}{$\begin{array}{c}\text { Weight } \\
\text { fraction, } \\
\text { wt. } \%\end{array}$} & RBC powder $\alpha$ & 0 & 5 \\
\hline & Carbon powder $\beta$ & 40 & 35 \\
\hline & Copper powder $\gamma$ & \multicolumn{2}{|c|}{60} \\
\hline \multicolumn{2}{|c|}{ Density $\rho, \mathrm{g} / \mathrm{cm}^{3}$} & 3.5 & 3.6 \\
\hline \multicolumn{2}{|c|}{ Electric resistivity $R, \mu \Omega \cdot \mathrm{m}$} & 1.2 & 2.0 \\
\hline \multicolumn{2}{|c|}{ Bending strength $\sigma_{\mathrm{B}}, \mathrm{MPa}$} & 108 & 106 \\
\hline \multicolumn{2}{|c|}{ Shore hardness $H S$} & 86 & 76 \\
\hline
\end{tabular}

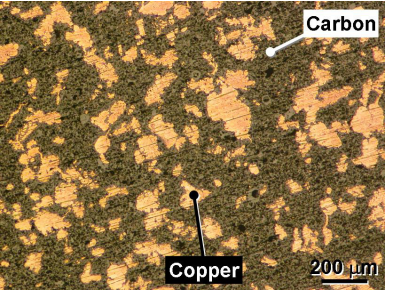

(a) $\mathrm{Cu} / \mathrm{C}$ composite

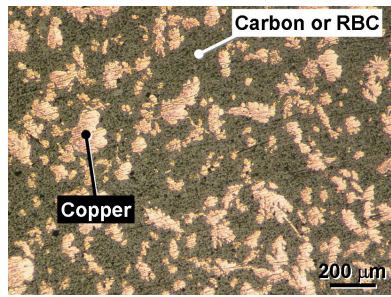

(b) $\mathrm{Cu} / \mathrm{C} / \mathrm{RBC}$ composite
Fig. 2 Optical microscope images of buffed surface of each composite

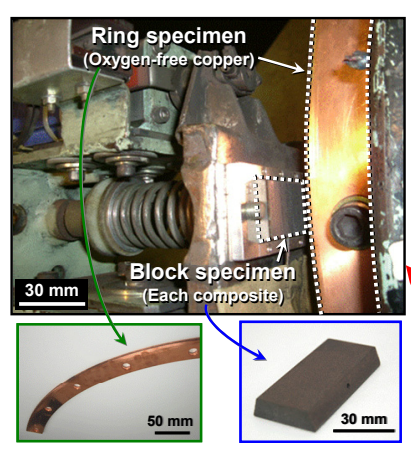

\section{Plan view}

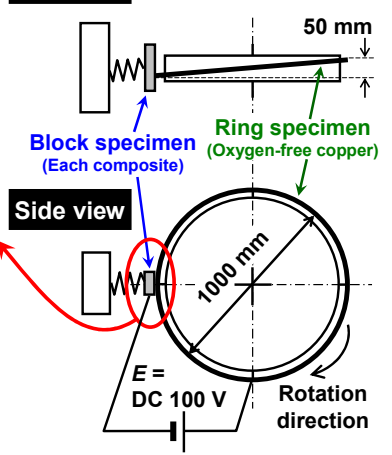

Fig. 3 Schematic diagram of block-on-ring friction apparatus used under electrical current

Table 2 Experimental condition

\begin{tabular}{|c|c|}
\hline Test condition & $\begin{array}{c}\text { Without arc-discharge, } \\
\text { With arc-discharge }\end{array}$ \\
\hline Block specimens & $\begin{array}{c}\mathrm{Cu} / \mathrm{C} \text { composite, } \\
\mathrm{Cu} / \mathrm{C} / \mathrm{RBC} \text { composite }\end{array}$ \\
\hline Ring specimen & Oxygen-free copper \\
\hline Normal load $W, \mathrm{~N}$ & 49 \\
\hline Sliding velocity $v, \mathrm{~m} / \mathrm{s}$ & 27.8 \\
\hline Sliding time $T, \mathrm{~min}$ & 30 \\
\hline Voltage of power supply $E, \mathrm{~V}$ & 100 (DC) \\
\hline & $\begin{array}{c}\text { Without arc-discharge }: \\
\text { Electrical current } I, \mathrm{~A}\end{array}$ \\
\cline { 2 - 2 } & $\begin{array}{c}\text { With arc-discharge : } \\
100,200,300,400\end{array}$ \\
\hline
\end{tabular}


electronic balance. Specific wear rates of the ring specimens were calculated based on a wear depth measured with the laser type surface profilometer.

\section{Experimental results and discussion}

\subsection{Friction and wear properties under electrical} current without arc-discharge

Figure 4 shows the relationship between friction coefficients and the number of repeat passages for each composite under electrical current without arc-discharge. The friction coefficient of the $\mathrm{Cu} / \mathrm{C}$ composite increased to around 0.25 at the initial stage of friction, and then gradually decreased with the number of repeat passages. The friction coefficient of the $\mathrm{Cu} / \mathrm{C} / \mathrm{RBC}$ composite very slightly increased up to around 0.08 at the initial stage of friction, and then gradually decreased with the number of repeat passages.

Figure 5 shows optical images of each block specimen after testing under electrical current without arc-discharge. The worn area of the $\mathrm{Cu} / \mathrm{C} / \mathrm{RBC}$ composite was significantly smaller than those of the $\mathrm{Cu} / \mathrm{C}$ composite.

Figure 6 shows the comprehensive tribological properties of each composite under electrical current without arc-discharge. The $\mathrm{Cu} / \mathrm{C} / \mathrm{RBC}$ composite showed the tribological properties significantly superior to the $\mathrm{Cu} / \mathrm{C}$ composite. The $\mathrm{Cu} / \mathrm{C} / \mathrm{RBC}$ composite showed $98 \%$ reduction in the specific wear rate of the block specimen, $23 \%$ reduction in that of the ring specimen, and $75 \%$ reduction in the friction coefficient over the conventional $\mathrm{Cu} / \mathrm{C}$ composite.

Figure 7 shows scanning electron microscope (SEM) images of the worn surfaces of each block specimen after testing under electrical current without arc-discharge. Plastic flows of the copper parts possibly caused by severe adhesion were observed on the worn surface of the $\mathrm{Cu} / \mathrm{C}$ composite. On the other hand, smoother surfaces and smaller areas of the copper parts were observed on the worn surface of the $\mathrm{Cu} / \mathrm{C} / \mathrm{RBC}$ composite.

In the $\mathrm{Cu} / \mathrm{C}$ composite, severe adhesion of copper/copper caused high specific wear rate greater than $10^{-7} \mathrm{~mm}^{2} / \mathrm{N}$. Additionally, expansion of real contact areas due to high wear produced the increase of friction coefficients at the initial stage of friction in Fig. 4. On the other hand in the $\mathrm{Cu} / \mathrm{C} / \mathrm{RBC}$ composite, severe adhesion of copper/copper hardly occurred. This

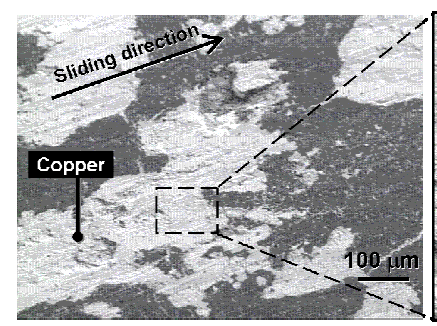

(a) $\mathrm{Cu} / \mathrm{C}$ composite non-occurrence prevented expansion of the copper areas. Thus, the friction coefficients took lower and more stable values regardless of the number of repeat passages.

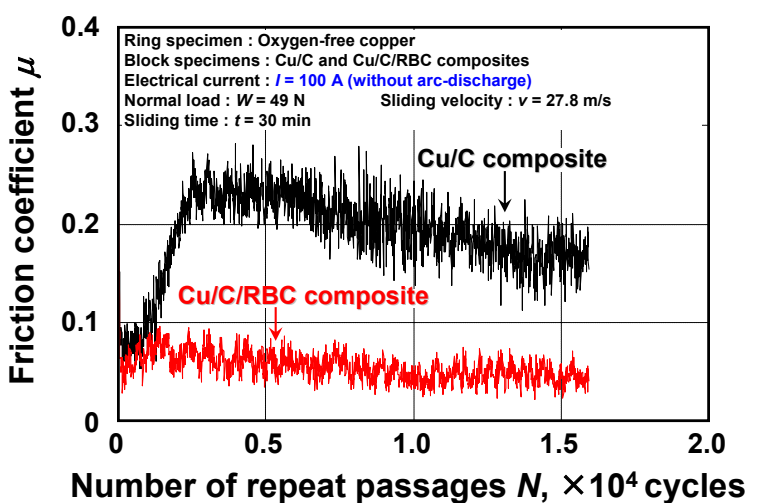

Fig. 4 Relationship between friction coefficient and number of repeat passages
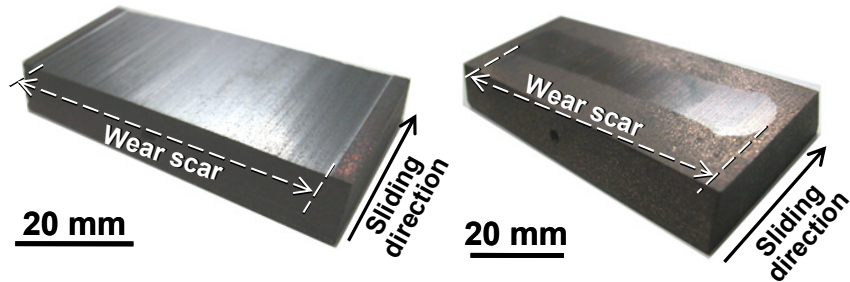

(a) $\mathrm{Cu} / \mathrm{C}$ composite

(b) $\mathrm{Cu} / \mathrm{C} / \mathrm{RBC}$ composite

Fig. 5 Optical images of each block specimen after testing without arc-discharge

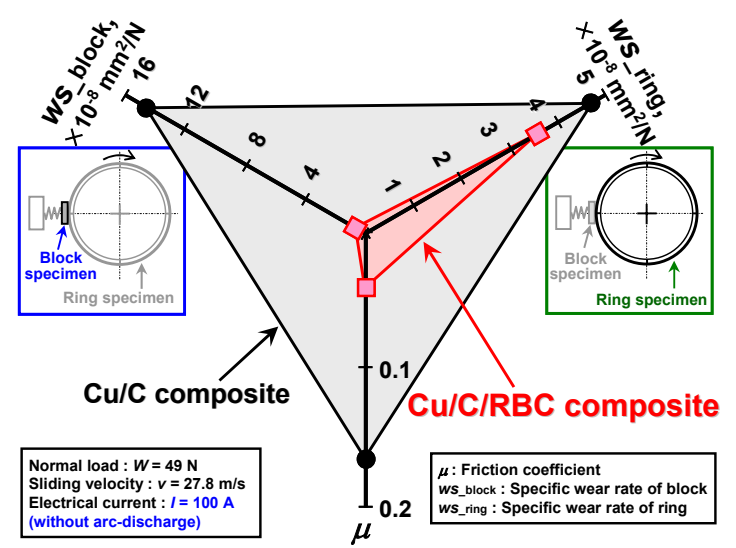

Fig. 6 Comprehensive tribological properties of each composite without arc-discharge

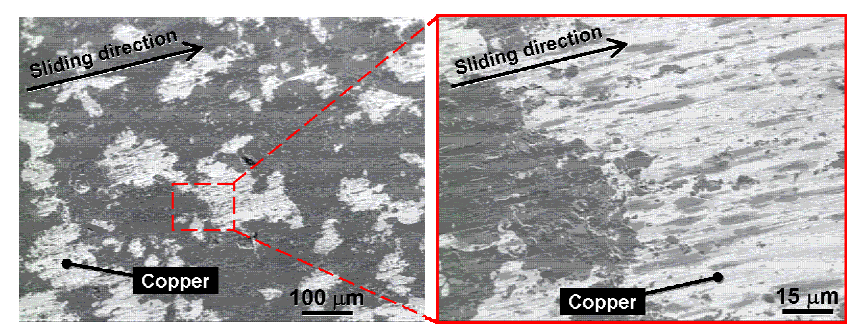

(b) $\mathrm{Cu} / \mathrm{C} / \mathrm{RBC}$ composite

Fig. 7 SEM images of worn surface of each block specimen after testing without arc-discharge 
3.2. Wear properties under electrical current with arc-discharge.

The specific wear rate of a slider material tends to increase with the arc-discharge rate $I_{\mathrm{A}}$ expressed by the following equation ${ }^{7)}$;

$$
I_{\mathrm{A}}=\frac{p}{100} \times I
$$

where, $p$ is average contact break ratio, $I$ is electrical current. Handa and $\mathrm{Kubo}^{7)}$ evaluated the wear resistance to arc-discharge by the slope of the approximate line between the specific wear rate of the block specimen and the arc-discharge rate $w s / I_{\mathrm{A}}$.

Figure 8 shows the relationship between specific wear rates of block specimens and arc-discharge rates. The specific wear rates of both composites linearly increased with the arc-discharge rate. Besides, the slopes of the approximated line for each composite was equal $\left(w s / I_{\mathrm{A}}=1.8 \times 10^{-8} \mathrm{~mm}^{2} \cdot \mathrm{s} /(\mathrm{N} \cdot \mathrm{C})\right)$, which indicates that the $\mathrm{Cu} / \mathrm{C} / \mathrm{RBC}$ composite showed the wear resistance to arc-discharge equivalent to the $\mathrm{Cu} / \mathrm{C}$ composite.

Figure 9 shows SEM images of the worn surfaces of each block specimen after testing under electrical current with arc-discharge. Wear particles of copper disappeared from the surfaces of both composites.

It can be considered that the dissipation of copper particles is caused by a high temperature over the melting point of copper.

On the basis of the experimental results, it can be concluded that the $\mathrm{Cu} / \mathrm{C} / \mathrm{RBC}$ composite has the tribological properties under electrical current without arc-discharge superior to the $\mathrm{Cu} / \mathrm{C}$ composite.

\section{Conclusions}

(1) $\mathrm{The} \mathrm{Cu} / \mathrm{C} / \mathrm{RBC}$ composite $\left(\alpha=5 \mathrm{wt} \%, d_{\mathrm{m}}=4.9 \mu \mathrm{m}\right)$ showed $98 \%$ reduction of in the specific wear rate of the block specimen, $23 \%$ in that of the ring specimen, and $75 \%$ in the friction coefficient over the conventional $\mathrm{Cu} / \mathrm{C}$ composite under electrical current without arc-discharge.

(2) The wear resistance to arc-discharge of the $\mathrm{Cu} / \mathrm{C} / \mathrm{RBC}$ composite was equivalent to that of the conventional $\mathrm{Cu} / \mathrm{C}$ composite.

\section{Acknowledgement}

The authors thank to Mr. Hiroshi Tsuchiya, Railway Technical Research Institute, Japan for his great contribution to the experiments.

\section{References}

[1] Kubo, S., "Latest Trend in Material for Pantograph's Contact Strip," Journal of Japanese Society of

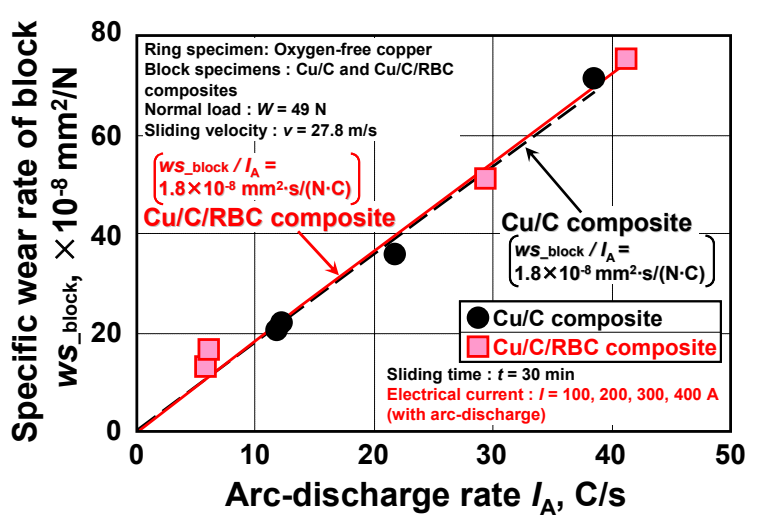

Fig. 8 Relationship between specific wear rate of block specimen and arc-discharge rate

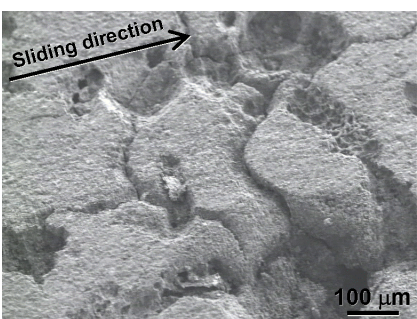

(a) $\mathrm{Cu} / \mathrm{C}$ composite

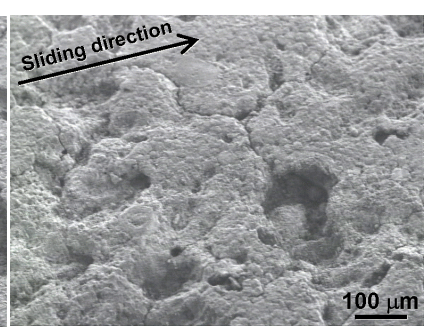

(b) $\mathrm{Cu} / \mathrm{C} / \mathrm{RBC}$ composite
Fig. 9 SEM images of worn surface of each block specimen after testing with arc-discharge

Tribologists, 50, 3, 2005, 202-207. (in Japanese)

[2] Shibata, K., Yamaguchi, T., Mishima, J. and Hokkirigawa, K., "Friction and Wear Properties of Copper/Carbon/RB Ceramics Composite Materials under Dry Condition," Tribology Online, 3, 4, 2008, 222-227.

[3] Hokkirigawa, K., Shikano, S. and Takahashi, T., "Development of Hard Porous Materials "RB Ceramics" Made of Rice Bran," Proc. $3^{\text {rd }}$ Int. Conf. on Ecomaterials, 1997, 132-135.

[4] Hokkirigawa, K., "Development and Application of Rice Bran Ceramics as a New Tribo-Material," Proc. Int. Conf. Nagasaki, 2000, 31-38.

[5] Yamaguchi, T. and Hokkirigawa, K., "Development of Hard Porous Carbon Materials RB Ceramics and Their Tribological Application," Proc. $3^{\text {rd }}$ Asia Int. Conf. Tribol., 2006, 387-388.

[6] Yamaguchi, T. and Hokkirigawa, K., "Tribological Properties and Applications of Hard Porous Carbon Materials "RB Ceramics"," Journal of Japanese Society of Tribologists, 52, 2, 2007, 114-119. (in Japanese)

[7] Handa, K. and Kubo, S., "Wear Properties of Bi-Added Cu-Based Sintered Alloys Sliding under Electric Current," Journal of Japanese Society of Tribologists, 51, 6, 2006, 456-462. (in Japanese) 